\title{
Whole Chia Flour as Yield Enhancer, Potential Antioxidant and Input of n-3 Fatty Acid in a Meat Product
}

\author{
Carola Noelia Riernersman1,2*, Romero Ana María², Doval Mirtha Marina², \\ Judis María Alicia² \\ ${ }^{1}$ Consejo Nacional de Investigaciones Científicas y Técnicas (CONICET), \\ Roque Sáenz Peña, Argentina \\ ${ }^{2}$ Universidad Nacional del Chaco Austral (UNCAus), Roque Sáenz Peña, \\ Argentina \\ Email: *carola@uncaus.edu.ar
}

Received 10 May 2016; accepted 21 August 2016; published 24 August 2016

Copyright (C) 2016 by authors and Scientific Research Publishing Inc.

This work is licensed under the Creative Commons Attribution International License (CC BY). http://creativecommons.org/licenses/by/4.0/

(c) (i) Open Access

\begin{abstract}
In this paper, the effect of the addition of whole chia flour and water at cooked fish burgers on yield, water and fat retention, $n-3$ fatty acids content and oxidative stability were studied. The results showed that $94 \%$ of yield, $92 \%$ of water retention and $97 \%$ of fat retention were achieved with the addition of $5.92 \mathrm{~g}$ of whole chia flour and $15 \mathrm{~g}$ of water per $100 \mathrm{~g}$ of burger. The n-3 fatty content increased from $704.57 \pm 21.66 \mathrm{mg}$ to $1551.71 \pm 47.71 \mathrm{mg} / 100 \mathrm{~g}$ of cooked burger when the chia flour was added, enhancing nutritional quality indices of lipid. A good oxidative stability, with minimum formation of conjugated dienes, hydroperoxides and thiobarbituric acid reactive substances during $\mathbf{3 0}$ days frozen storage was obtained too, probably due to the presence of polyphenolic compounds with antiradical activity and reducing power in the fibrous fraction of the flour chia. The results from the present study highlight remarkable technological applications of whole chia flour as food ingredient in the design of healthier fish meat commodities.
\end{abstract}

\section{Keywords}

Freshwater Fish, Whole Chia Flour, Potential Antioxidant, Yield, Fortified Foods

\section{Introduction}

At present, food industries are investing in the development of new beneficial food products; in this sense, "Corresponding author.

How to cite this paper: Riernersman, C.N., María, R.A., Marina, D.M. and Alicia, J.M. (2016) Whole Chia Flour as Yield Enhancer, Potential Antioxidant and Input of n-3 Fatty Acid in a Meat Product. Food and Nutrition Sciences, 7, 855-865. 
products have been marketed as "low fat" or "light" in saturated fatty acids (SFA), enriched with n-9, n-3 and/or n-6 fatty acids. To achieve this, they have resorted to the incorporation of a wide variety of ingredients into foods, whose consumption could prevent diseases, such as flax seed [1] and chia seed among others, as well as in oils rich in unsaturated fatty acids [2], including sunflower oil [3] and olive oil [4]. Other good sources of unsaturated fatty acids are products of ictio origin, fish meats and oils [5] mainly of marine origin.

The river fish have lipids with less n-3 fatty acids content than seafish [6], but they represent an attractive alternative to design and technological development of new fortified products especially when the access to seafood is limited due to the long distances from distribution centers, being for this reason more expensive. One of the most consumed water fish from Paraná River is the spotted catfish (Pseudoplatystoma corruscans). This fish, wich belongs to the family Pimelodidae, is characterized by a high fat content (12.2 g/100g), being also an important source of protein. This fat contains mainly triglycerides of unsaturated fatty acids ( $56 \%$ of the total fat) among which are the monounsaturated fatty acids (MUFA) n-9 oleic acid, and the polyunsaturated fatty acids (PUFA) n-6 linoleic acid and n-3 docosahexaenoic acid (DHA) [7].

With respect to meat and processed derivatives, storage and cooking are necessary for safe and palatable product but these methods may also play a significant role in the development of oxidation processes, which affect the physic-chemical state of proteins and their amino acid bioavailability [8]. It may also affect the lipid composition of the meat, especially favors the loss of essential fatty acids and consequently, reducing the nutritional value [9]. Also, depending on the intensity and duration of heat treatment, as well as the intrinsic characteristics of the meat emulsion, many authors have reported significant weight loss, water and fat after the meat products have undergone cooking and storage [10]-[12]. So it is necessary to incorporate different additives to try to minimize this negative effect.

Chia seed (Salvia hispanica L.) contains between 30 - $33.5 \mathrm{~g}$ oil/100g with high concentrations of polyunsaturated fatty acids (PUFA), being $\alpha$-linolenic acid (ALA), a n-3 fatty acid the main essential fatty acid present in it (57 - $65 \mathrm{~g} / 100 \mathrm{~g}$ ) [13]. Another benefit of chia seed is its high fiber with excellent technological properties as a texturizing, stabilizing, which intervenes in the gel formation, improves the ability of water and fat retention, etc., among other properties [14] [15]. In addition, it is known that the chia seeds [16] containsa great amount of polyphenolic compounds with potent antioxidant activity, mainly flavonoids such as quercetin, kaempferol, myricetin and others. The insoluble fraction of the chia flour (dehydrated and degreased fraction) also showed antioxidant activity comparable to that of Trolox [17]. It is important to highlight the nutritional importance of chia seeds, which make them, an ideal ingredient to add a great number of culinary preparations.

Therefore, bring together the benefits of one freshwater fish with a rich source of n-3 fatty acids, such as whole chia flour, in only one product seems to be an interesting perspective.

The aims of this research were: 1) to optimize the effect of addition of different levels of whole chia flour and water on the technological parameters (yield, water and lipids retention) of precooked surubi meat burgers; 2) to evaluate the changes on nutritional values of the optimized burgers with the whole chia flour addition; 3 ) to characterize fibrous fraction of whole chia flour used in this research with respect to its antioxidant properties and 4) to analyze the oxidative stability of the precooked products during storage frozen.

\section{Materials and Methods}

\subsection{Materials and Samples}

Samples of stained surubi specimen (Pseudoplatystoma corruscans) were extracted from Parana River (27 $17^{\prime} 30^{\prime \prime S}$ latitude and $58^{\circ} 59^{\prime} 50^{\prime \prime} \mathrm{W}$ longitude) by fishermen through trawls. The specimens once sacrificed were eviscerated and their head and tail removed in the place of arrival of the boats; immediately the pieces of fish were transferred under refrigeration at Food Industries II laboratory.

Chia seeds were provided by Nutraceutica Sturla SRL (Argentina) from crops grown in Salta state ( $25^{\circ} 04^{\prime} 02^{\prime \prime S}$ latitude and $65.5^{\circ} 28^{\prime} 00^{\prime \prime} \mathrm{W}$ longitude) and kept in plastic packages hermetically sealed to $5^{\circ} \mathrm{C} \pm 1^{\circ} \mathrm{C}$. Then, whole chia flour (moisture: $4.35 \mathrm{~g} / 100 \mathrm{~g}$, protein: $17.90 \mathrm{~g} / 100 \mathrm{~g}$, fat: $37.11 \mathrm{~g} / 100 \mathrm{~g}$, carbohydrates: 35.76 $\mathrm{g} / 100$ and ash: $5.07 \mathrm{~g} / 100 \mathrm{~g}$ ) was obtained by grinding through a concentric disc manual grinder (Toolcraft ${ }^{\circledR}$ tc 2541) and frozen at $-18^{\circ} \mathrm{C}$ until its use.

\subsection{Burger Manufacture}

Fish meat was ground and emulsified with Philips ${ }^{\circledR}$ processor for 3 minutes. $\mathrm{NaCl}$ (2 g/100g and sodium poly- 
phosphate $\left(0.5 \mathrm{~g} / 100 \mathrm{~g}-\right.$ Bernecol $\left.^{\circledR}\right)$ were mixed with emulsion. The amounts of whole chia flour and water were added according to a factorial multilevel design. The mixes were kneaded for 15 minutes and then were molded in samples of approximately $100 \mathrm{~g}$ each one (100 mm of diameter and $20 \mathrm{~mm}$ of height). Afterward, one batch of meat burger was cooked in a static oven $\left(\mathrm{Tecnodalvo}^{\circledR}\right.$ ) at $200^{\circ} \mathrm{C}$ for 15 minutes until the thermal center reached $73^{\circ} \mathrm{C}$ during 15 seconds to reach food safety; and another batch was left raw for control. The burgers were weighed before and after cooking to calculate cook losses. Once cooked and cooled, they were packed in polyethylene film with an oxygen permeability $2000 \mathrm{~cm}^{3} / \mathrm{m}^{2} 24 \mathrm{~h}$ and frozen at $-18^{\circ} \mathrm{C}$.

\subsection{Experimental Design}

The factorial multilevel design adopted was $3^{2}$ (two factors with three levels). The levels of the water factor were A: $15 \mathrm{~g}, \mathrm{~B}: 25 \mathrm{~g}$ and C: $35 \mathrm{~g}$ per $100 \mathrm{~g}$, and the levels of whole chia flour factor, E: $0 \mathrm{~g}, \mathrm{~F}: 5 \mathrm{~g}$ and G: $10 \mathrm{~g}$ per $100 \mathrm{~g}$. A response surface methodology was used to analyze the effect of the two independent variables (water and whole chia flour) on the responses (yield, water and lipid retention). The treatment structure was completely randomized with 2 replications. A multiresponse optimization was used to find the optimum formulation, using a desirability function approach which is based on the idea that the "quality" of a product or process has multiple quality characteristics, with none of them outside some "desired" limits. The method finds operating conditions that provide the "most desirable" response values [18]. The individual maximum response function to yield, lipid and water retention was combined and the maximum desirability was obtained.

\subsection{Cooking Measurements}

Cooking yield, and the lipids and water retention of burgers were calculated as follows:

$$
\text { Yield }(\%)=(\text { Cooked Product Weight } / \text { Raw Product Weight })
$$

Water Retention $(\%)=($ Water Cooked Product Weight/Water Raw Product Weight $) * 100$

Lipid Retention $(\%)=($ Lipid Cooked Product Weight/Lipid Raw Product Weight $) * 100$

\subsection{Chemical Analysis}

\subsubsection{Proximate Analysis}

Moisture was determined by weight loss after $24 \mathrm{~h}$ at $105^{\circ} \mathrm{C}$ in an assisted air circulation oven according to AOAC Method 950.46 [19]. Crude protein content was analyzed by the Kjeldahl procedure (AOAC Method 960.52) [19] and the fat content was determined in samples previously dried by the Söxhlet method, using petroleum ether $\left(\mathrm{B}_{\mathrm{p}}: 30^{\circ} \mathrm{C}-60^{\circ} \mathrm{C}\right)$ as extraction solvent. Proximate composition of burgers was done in triplicate. Total dietary fiber (TDF) was determined by an enzymatic-gravimetric method (AOAC Method 985.29) [19].

\subsubsection{Fatty Acid Composition and Nutritional Quality of Lipids}

Extraction and purification of fat were performed according to the method of Bligh \& Dyer (1959) [20]. The fatty acid methyl esters were prepared according to the technique of the AOAC Method 969.33 [19], and quantified with Agilent Technologies gas chromatograph equipped with a 60 capillary column Supelco $2340^{\circledR}$ and a FID detector. The oven temperature was held at $140^{\circ} \mathrm{C}$ for $5 \mathrm{~min}$ and subsequently increased to $4^{\circ} \mathrm{C} / \mathrm{min}$ to reach $240^{\circ} \mathrm{C}$ and maintained this temperature for $15 \mathrm{~min}$. Identification of fatty acid methyl esters was based on retention time of standard methyl esters (Supelco ${ }^{\circledR} 37$ Components FAME Mixture, Bellefonte, PA), plus Conjugated Linoleic Acids (Sigma-Aldrich) and Methyl cis-7, 10, 13, 16, 19-Docosapentaenoate (Supelco) eluting from the capillary column. Peak areas were integrated using chromatography data software, and concentrations of each ester were calculated as a percentage of the total area of the chromatogram. Data were expressed as mg fatty acid per 100 grams of product. The Index of Atherogenicity (IA) [21], Index of Thrombogenicity (IT) [21] and HH [22] were calculated as follows:

$$
\begin{aligned}
& I A=[C 12: 0+(4 \times C 14: 0)+C 16: 0] /[\Sigma M U F A+\Sigma n-6 P U F A+\Sigma n-3 P U F A] \\
& I T= {[C 14: 0+C 16: 0+C 18: 0] /[(0.5 \times \Sigma M U F A)+(0.5 \times \Sigma n-6 P U F A)} \\
&+(3 \times \Sigma n-3 P U F A)+(\Sigma n-3 P U F A / \Sigma n-6 P U F A)]
\end{aligned}
$$




$$
\begin{aligned}
H H= & (C 18: 1 c i s 9+C 18: 2 n-6+C 20: 4 n-6+C 18: 3 n-3+C 20: 5 n-3 \\
& +C 22: 5 n-3+C 22: 6 n-3) /(C 14: 0+C 16: 0)
\end{aligned}
$$

\subsubsection{Antioxidant Properties of Chia Flour}

1) Preparation of extracts

The whole chia flour was previewed degreased and dried to obtain only the fibrous fraction. The extracts for analysis of antioxidant properties were obtained by dissolving the fibrous fraction in $70 \%$ ethanol overnight in a shaker at room temperature, and subsequent filtration through $0.45 \mu \mathrm{m}$.

2) Analysis of antioxidant properties

The Folin-Ciocalteu reagent assay was used to determine the total phenolic content [23] [24]. At $1 \mathrm{ml}$ sample, distilled water was added to obtain $10 \mathrm{ml}$ solution, followed by addition of $0.5 \mathrm{ml}$ of Folin-Ciocalteu reagent. After 5 minutes, $1 \mathrm{ml}$ of saturated sodium carbonate $\left(\mathrm{Na}_{2} \mathrm{CO}_{3}\right)$ was added and then kept in darkness for an hour. Subsequently, the absorbance at $735 \mathrm{~nm}$ was measured. The total phenolic content was expressed as $\mathrm{mg}$ gallic acid equivalent (GAE) per gram of dry matter.

The determination of the free radicals scavenging capacity of fibrous fraction of whole chia flour was determined on $\mathrm{DPPH}^{*}$ (1,1-diphenyl-2-picrylhydrazyl radical) and $\mathrm{ABTS}^{*+}$, [2,2'-Azino-bis(3-ethylbenzothiazoline6-sulfonic acid] radical cation.

Both assays were carry out according to the method descript by Siddhuraju et al. (2002) [25]. Ascorbic acid (AA) was used as a reference and the spectrophotometric methods consisted in measuring the decrease in absorbance at $517 \mathrm{~nm}$ and $734 \mathrm{~nm}$ respectively, of $10 \mu \mathrm{l}$ samples added to $3 \mathrm{ml}$ of the DPPH' solution $\left(10^{-3} \mathrm{M}\right)$ and $\mathrm{ABTS}^{*+}$ radical cation solution $\left(7 \times 10^{-3} \mathrm{M}\right)$ for 10 minutes at room temperature. The absorbance was read in a UV-Vis spectrophotometer (Thermo Scientific UV-Vis, Evolution 600). The results were expressed as mg of vitamin $\mathrm{C}$ equivalent (AAE) per gram of dry matter, using as reference a standard curve.

The reducing power was determined according to the method of potassium ferricyanide in presence of ferric chloride [26], by measuring absorbance at $700 \mathrm{~nm}$. Ascorbic acid was used as standard, expressing the results in $\mathrm{mg}$ of vitamin $\mathrm{C}$ equivalents (AAE) per gram of dry matter.

\subsubsection{Evaluation of Oxidative Stability of Optimized Burger}

The cooked fish burgers stored at $-18^{\circ} \mathrm{C}$ for 90 days were sampled at $0,30,60$ and 90 days.

The evaluation of lipid oxidation was based on the determination of primary and secondary lipid oxidation products. The primary lipid oxidation products included conjugated dienes and lipid hydroperoxides, whereas the secondary lipid oxidation products were determined as malondiadehyde.

Conjugated dienes (CD) were quantified spectrophotometrically according to the AOAC Method 957.13 [19] of polyunsaturated fats and oils. $10 \pm 2 \mathrm{mg}$ of fat was weighed and dissolved in $4 \mathrm{ml}$ of hexane. The absorbance was measured at $233 \mathrm{~nm}$ in a UV-Vis spectrophotometer (Thermo Scientific UV-Vis, Evolution 600). Data were expressed in mg of conjugated linoleic acid (CLA) equivalent per gram of fat, using a calibration curve of conjugated linoleic acid (Sigma Aldrich), according toPonginebbi et al. (1999) [27].

Lipid hydroperoxides were determined according to the FIL-IDF 74A method (International Dairy Federation 1991) [28] slightly modified. Lipids (2 - $5 \mathrm{mg}$ depending on the extent of peroxidation), were mixed with $9.9 \mathrm{ml}$ chloroform-methanol $(70: 30 \mathrm{v} / \mathrm{v})$ in a glass tube. Ammonium thiocyanate solution $(0.05 \mathrm{ml})$ was added and the sample was mixed again. Then $0.05 \mathrm{ml}$ iron II from a ferrous chloride solution was added to reaction mixture and after $5 \mathrm{~min}$ incubation at room temperature, the absorbance was measured at $500 \mathrm{~nm}$. The results of peroxide value (PV) were expressed in milliequivalents of peroxides per $\mathrm{kg}$ fat.

The secondary oxidation products of lipid oxidation were measured as TBARS (thiobarbituric acid reactive substances) by spectrophotometric method described by Romero et al. (2005) [29]. TBARS were expressed as mg of malondialdehyde (MDA) per kg of fat in samples using 1, 1, 3, 3-tetramethoxypropane (TEP) as a standard.

\subsubsection{Statistical Analysis}

All results were expressed as mean \pm standard deviation $(\mathrm{M} \pm \mathrm{SD}$ ) and an analysis of one-way variance (ANOVA) was applied. To media comparisons the Tukey's test was used ( $\mathrm{p}$ value $<0.05$ ). 


\section{Results and Discussion}

\subsection{Optimization of the Formulation}

Table 1 gives codification, Yield (\% w/w) Water and Lipid Retention (\% w/w) for all tested formulations of burgers. The factor 1 (Water) decreased significantly the yield, water and lipid retentions, while factor 2 (Whole chia flour) influenced positively on the response variables and showed a parabolic behavior.

The decreasing of cooking yield and water and the lipid retention obtained when the water addition was increased is according to Velioğlu et al. (2010) [11], who reported that the yield by cooking decreased when the amount of water in the formulation of beef burgers was increased. Valenzuela Melendres et al. (2014) [30] also found that the addition of tomato paste with high water content to beef burgers produced a decreased cooking yield and that could be due to an increase in the percentage of moisture in the product.

On the other hand, the flour chia addition showed a different behavior in cooking yield of beef burgers presenting higher percentages, except to $10 \%$ of chia flour and 35\% of water. Valenzuela Melendres et al. (2014) [30] reported that flaxseed flour produced an increment of the dry matter of the beef burgers, and then a higher cooked yield.

The optimization criteria were to maximize yield and water and lipid retention. The mathematical model used to find a global desirability value is a geometric media of individual desirability values. Figure 1 shows the desirability function to water and whole chia flour for Yield (\%w/w) Water and Lipid Retention (\% w/w) in all formulations tested burgers. The optimum combination of ingredients to add intosurubí burgers were $15 \mathrm{~g}$ of water $(-1)$ and 5.92 of whole chia flour (0.18) per $100 \mathrm{~g}$ of product, with a global or overall desirability of 0.98 . The optimal formulation gave a cooking yield of $93.94 \% \pm 0.41 \% \mathrm{w} / \mathrm{w}$ and moisture content of $70.36 \% \pm 0.34 \%$ $\mathrm{w} / \mathrm{w}$ and fat content of $7.27 \% \pm 0.10 \% \mathrm{w} / \mathrm{w}$.

As regards lipid and water retention, the optimal formulation retained $97.10 \% \pm 0.31 \% \mathrm{w} / \mathrm{w}$ and $91.87 \% \pm$ $0.27 \% \mathrm{w} / \mathrm{w}$ respectively. Higher fat and moisture retention of optimal burgers can be attributed to binding and stabilizing effect produced by the fibrous portion of whole flour chia [15]. This is according to Anderson \& Berry (2001) [31], who hypothesized that the mechanism of water and fat retention could be predominantly physical. Then, the swelling of the starch and the fiber, in addition to some fat absorption by the fiber, could interact with the protein of the ground meat to form a matrix, which would prevent the coalescence and migration of fat from coming out of the product.

\subsection{Nutritional Value and Lipid Profile}

To evaluate changes in nutritional value, the control burger (formulation without adding chia flour) and the burger added with $5.92 \mathrm{~g} / 100 \mathrm{~g}$ the whole chia flour (Optimal), both cooked and stored at $-18^{\circ} \mathrm{C}$ for 90 days were compared.

Table 1. Yield, water and lipid retention of burgers (\% w/w).

\begin{tabular}{|c|c|c|c|c|c|c|c|}
\hline \multirow{2}{*}{ Formulation } & \multicolumn{2}{|c|}{ Water } & \multicolumn{2}{|c|}{ Whole chia flour } & \multirow{2}{*}{$\begin{array}{c}\text { Yield } \\
(\% \mathrm{w} / \mathrm{w})\end{array}$} & \multirow{2}{*}{$\begin{array}{l}\text { Water retention } \\
\quad(\% \mathrm{w} / \mathrm{w})\end{array}$} & \multirow{2}{*}{$\begin{array}{l}\text { Lipid retention } \\
(\% \mathrm{w} / \mathrm{w})\end{array}$} \\
\hline & Codified & $g / 100 g$ & Codified & $g / 100 g$ & & & \\
\hline $\mathrm{AE}$ & -1 & 15 & -1 & 0 & $92.52^{\mathrm{a}} \pm 0.06$ & $90.13^{\mathrm{b}} \pm 0.31$ & $80.65^{b} \pm 0.51$ \\
\hline $\mathrm{BE}$ & 0 & 25 & -1 & 0 & $92.70^{\mathrm{a}} \pm 0.24$ & $90.82^{\mathrm{b}} \pm 0.95$ & $83.84^{b} \pm 0.76$ \\
\hline $\mathrm{CE}$ & 1 & 35 & -1 & 0 & $92.78^{\mathrm{a}} \pm 0.37$ & $90.31^{b} \pm 0.22$ & $92.97^{b} \pm 1.53$ \\
\hline $\mathrm{AF}$ & -1 & 15 & 0 & 5 & $94.24^{\mathrm{b}} \pm 0.41$ & $92.19^{\mathrm{a}} \pm 0.27$ & $95.67^{\mathrm{a}} \pm 0.41$ \\
\hline $\mathrm{BF}$ & 0 & 25 & 0 & 5 & $93.58^{\mathrm{ab}} \pm 0.12$ & $91.08^{\mathrm{ab}} \pm 0.02$ & $91.62^{\mathrm{ab}} \pm 2.82$ \\
\hline CF & 1 & 35 & 0 & 5 & $93.08^{\mathrm{ab}} \pm 0.54$ & $91.06^{\mathrm{ab}} \pm 2.06$ & $96.71^{\mathrm{ab}} \pm 8.61$ \\
\hline AG & -1 & 15 & 1 & 10 & $93.42^{\mathrm{ab}} \pm 0.34$ & $90.61^{\mathrm{ab}} \pm 0.11$ & $96.11^{\mathrm{ab}} \pm 0.24$ \\
\hline BG & 0 & 25 & 1 & 10 & $93.11^{\mathrm{ab}} \pm 0.21$ & $89.53^{\mathrm{ab}} \pm 0.36$ & $80.87^{\mathrm{ab}} \pm 2.78$ \\
\hline CG & 1 & 35 & 1 & 10 & $92.86^{\mathrm{a}} \pm 0.01$ & $88.98^{\mathrm{b}} \pm 1.48$ & $74.69^{b} \pm 6.83$ \\
\hline
\end{tabular}

Different letters in the same column indicate significant differences $(\mathrm{p}<0.05)$. 


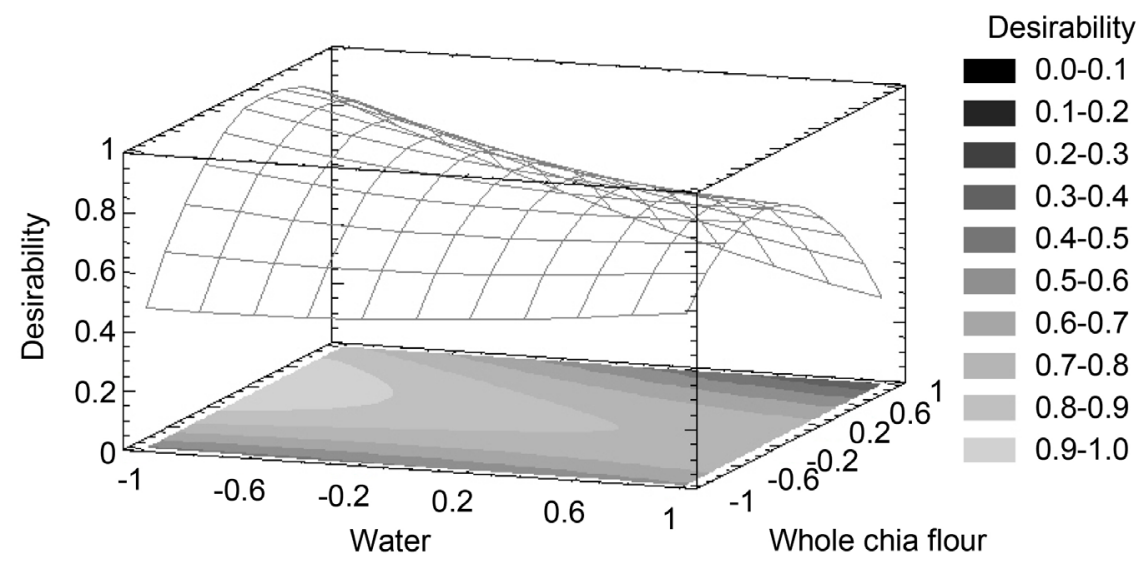

Figure 1. Response surface for overall desirability. It combined individual maximum desirability function to yield, lipid and water retention. Desirability was maximized with respect to water and whole chia flour contents expressed as codified values. The lighter shade indicates highest value.

The moisture content decreased slightly from $74.05 \pm 0.01$ to $70.36 \pm 0.34 \mathrm{~g} / 100 \mathrm{~g}$ and protein content varied from $18.57 \pm 0.13$ to $17.47 \pm 0.77 \mathrm{~g} / 100 \mathrm{~g}$ respectively. Optimization of the product showed a small loss of water and no change in protein content after cooking ( $<$ 0.5). Gök et al. (2011) [32] observed a similar behavior in moisture content, a reduction in fat level and an increase in protein content for meatballs with fat replaced with $20 \mathrm{~g}$ of ground poppy seeds per each $100 \mathrm{~g}$ with respect to control. Moreover, the optimized hamburger provided dietary fiber ( $4.23 \pm 0.36 \mathrm{~g} / 100 \mathrm{~g}$ of product) whiles the control hamburger did not contribute with fiber.

The addition of $5.92 \mathrm{~g}$ whole chia flour to the formulation increased the total fat content from $9.42 \pm 0.03$ to $10.19 \pm 0.10 \mathrm{~g} / 100 \mathrm{~g}$, and the fatty acid profile of the control and the optimal burger, cooked and stored at $-18^{\circ} \mathrm{C}$ for 90 days are shown in the Table 2.

In the optimal burger the n-3 fatty acids content was $1551.71 \pm 47.71 \mathrm{mg}$ of $\mathrm{n}-3 / 100 \mathrm{~g}$ of burgers, doubling the content of control (704.57 $\pm 21.66 \mathrm{mg}$ of $\mathrm{n}-3 / 100 \mathrm{~g}$ of burgers), being $1237.13 \pm 38.03 \mathrm{mg} / 100 \mathrm{~g}$ provided by ALA, and $214.41 \pm 6.59 \mathrm{mg} / \mathrm{g}$ by the docosahexaenoic acid (DHA) plus the eicosapentaenoic acid (EPA), thereby increasing the contribution of n-3 fatty acids of marked form.

This significant n-3 contribution is probable due to high amounts of fat present in chia flour (30\% approx.), where the content of alpha linolenic acid represents the $60 \%$ of the total fatty acids approximately [13].

That is according to Delgado-Pando et al. (2010) [33], who reported that, in the frankfurters with $11.5 \mathrm{~g}$ fat/100g of product, $2.5 \mathrm{~g} / 100 \mathrm{~g}$ were n-3 PUFAs (2 g/100g of ALA and $500 \mathrm{mg} / 100 \mathrm{~g}$ of EPA and DHA), when the pork backfat was replaced with healthier oils combination (olive, linseed and fish oils).

Considering that the dietary recommendation of health world organizations establish that it is necessary to consume between 1.4 and $3 \mathrm{~g}$ of n-3 PUFAs/day, and between 180 and $1000 \mathrm{mg} /$ day for the long chain n-3 PUFAs, 100g this product would satisfy this recommendation.

In the same way, the human diets should have a PUFA/SFA ratio above 0.45 [34] and n-6/n-3 fatty acids ratio between $1: 1$ and 2:1 [35], because lower ratios of PUFA/SFA or higher $n-6 / n-3$ fatty acids ratio in the diet increase the incidence of cardiovascular diseases [36].

In this study, the PUFA/SFA ratio in burgers increased from 1.02 (control burger) to 1.77 (optimal burger) and the $n-6 / n-3$ ratio decreased from 1.25 in control to 0.76 in optimal formulation (Table 2). Although the optimal formulation became healthier, the $n-6 / n-3$ ratio value is still above the recommendations for fat intake, however, it is very lower than 10 , value informed for western diets the $n-6 / n-3$ ratio.

On the other hand, in western diets the n-6/n-3 ratio was recently increased from 10:1 to 20:1 (due to a high n-6 proportion in the diet, largely made up by linoleic acid from vegetable oils) which is highly inappropriate for normal growth and development of human [35].

The indexes of atherogenicity (IA) and thrombogenicity (IT) were also lower when the chia flour was added (Table 2). These indexes indicate the potential to promote platelet aggregation. So, fats with low values of IA and IT can inhibit the aggregation of platelets and decrease the levels of esterified fatty acids, cholesterol and 
Table 2. Fatty acid composition and nutritional quality indexes of lipids from cooked and stored at $-18^{\circ} \mathrm{C}$ for 90 days burgers. Control (without chia flour added) and optimal (with the whole chia flour added).

\begin{tabular}{|c|c|c|}
\hline \multirow{2}{*}{ Fatty Acids Indexes ${ }^{*}$} & \multicolumn{2}{|c|}{ Burger } \\
\hline & Control & Optimal \\
\hline$\Sigma \mathrm{n}-3$ & $704.57 \pm 21.66^{\mathrm{a}}$ & $1551.71 \pm 47.71^{\mathrm{b}}$ \\
\hline$\Sigma \mathrm{n}-6$ & $880.93 \pm 27.08^{\mathrm{a}}$ & $1185.39 \pm 36.44^{\mathrm{b}}$ \\
\hline$\Sigma \mathrm{n}-9$ & $1666.24 \pm 51.23^{\mathrm{a}}$ & $1587.91 \pm 48.82^{\mathrm{a}}$ \\
\hline$\Sigma$ SFA & $1561.46 \pm 48.01^{\mathrm{a}}$ & $1550.71 \pm 47.67^{\mathrm{a}}$ \\
\hline$\Sigma$ MUFA & $2009.77 \pm 61.79^{\mathrm{a}}$ & $1933.46 \pm 59.44^{\mathrm{a}}$ \\
\hline$\Sigma$ PUFA & $1585.49 \pm 48.74^{\mathrm{a}}$ & $2737.10 \pm 84.15^{\mathrm{b}}$ \\
\hline n-3 ALA & $349.52 \pm 10.75^{\mathrm{a}}$ & $1237.13 \pm 38.03^{b}$ \\
\hline n-3 EPA + DHA & $241.67 \pm 7.43^{\mathrm{b}}$ & $214.41 \pm 6.59^{\mathrm{a}}$ \\
\hline$n-6 / n-3$ & $1.25 \pm 0.00^{\mathrm{b}}$ & $0.76 \pm 0.00^{\mathrm{a}}$ \\
\hline $\mathrm{P} / \mathrm{S}$ & $1.02 \pm 0.00^{\mathrm{a}}$ & $1.77 \pm 0.00^{\mathrm{b}}$ \\
\hline IA & $0.38 \pm 0.00^{\mathrm{b}}$ & $0.28 \pm 0.00^{\mathrm{a}}$ \\
\hline IT & $0.41 \pm 0.00^{\mathrm{b}}$ & $0.23 \pm 0.00^{\mathrm{a}}$ \\
\hline $\mathrm{HH}$ & $2.44 \pm 0.00^{\mathrm{a}}$ & $3.47 \pm 0.00^{\mathrm{b}}$ \\
\hline
\end{tabular}

${ }^{*}$ Means \pm standard error. Different letters in the same row indicate significant differences $(\mathrm{p}<0.05)$. Data were expressed as mg fatty acids/gram of fat.

phospholipids, thereby preventing the appearance of micro and macrocoronary diseases [21].

According to Tonial et al. (2011) [37], there are no recommended values for IA and IT, but it is understood that lower values of these indexes indicate a healthier ratio. In this study, the addition of whole chia flour reduced the IA and the IT significantly $(\mathrm{p}<0.05)$. Similar IA and IT indexes values have been reported in enriched frankfurters with replacement of pork backfat with konjac gel and by the addition of healthier oils stabilized [38].

According to Santos-Silva et al. (2002) [22], a higher HH ratio indicates a more suitable nutritionally food. The HH index value of cooked optimal burger was higher than the control, reaching values lower than those reported by Fuchs et al. (2013) [39] when Nile tilapia croquettes were enriched with $12.5 \mathrm{~g}$ of flaxseed flour per $100 \mathrm{~g}$ (HH ratio of 7.90), however, it is appropriate to note that the burger with chia flour added showed an increase of $40 \%$ of $\mathrm{HH}$ index.

\subsection{Antioxidant Properties of Fibrous Fraction of Chia Flour}

The fibrous fraction hydroalcoholic extracts of whole chia flour had a polyphenol content of $5.28 \pm 0.10 \mathrm{mg}$ GAE per gram of dry matter. This result was higher than the informed in other foods such as sesame cakes (1.94 mg GAE per gram of dry matter) [40] but less than alcoholic extracts of Salvia ringens (208.27 mg GAE/g dry extract) [41].

Free radicals capture capacity equivalent were $5.10 \pm 0.18 \mathrm{mg}$ AAE/g of dry matter for $\mathrm{DPPH}$ and $3.73 \pm 0.05$ mg AAE/g of dry matter for ABTS ${ }^{*+}$ per gram. These values were higher than those found by other authors. Chaalal M. et al. (2013) [42] reported that prickly pear seeds of red-yellow variety exhibited the strongest scavenging capacity on $\mathrm{DPPH}^{*}(0.9081 \mathrm{mg} \mathrm{AAE} / \mathrm{g}$ for whole seeds and $1.147 \mathrm{mg} \mathrm{AAE} / \mathrm{g}$ for ground seeds) while that Alimpic et al. (2015) [41] informed that the scavenging activity on $\mathrm{ABTS}^{*+}$ radicals were $2.44 \mathrm{mg} \mathrm{AAE} / \mathrm{g}$ dry extract to alcoholic extracts of Salvia ringens.

The fibrous fraction hydroalcoholic extracts of whole chia flour presented a reducing power of $0.50 \pm 0.01 \mathrm{mg}$ of AAE equivalent per gram of dry matter. Amarowicz et al. (2000) [43] expressed the reducing power is a function of the total concentration of polyphenols, so a high content of polyphenolic supposed a good reducing power. Duh et al. (1997) [44], Manian et al. (2008) [45] and Rumbaoa et al. (2009) [46] also reached to similar conclusions. 


\subsection{Evaluation of Lipid Oxidation in Burger}

Table 3 shows the effect of whole chia flour on DC, VP and TBARS values of cooked fish burger during storage at $-18^{\circ} \mathrm{C}$ for 90 days. As the unsaturated fatty acids from natural product presents double bonds interrupted by methylene groups, when their oxidation occurs, the double bonds shift to create conjugated systems, which can then be measured spectrophotometrically [47].

The burger without adding chia flour reached higher values that those with the whole chia flour added. This means that the incorporation of whole chia flour retarded the formation of CD in cooked fish burger until 30 days of storage, losing its effect at 60 days.

The hydroperoxides are primary oxidation products that determine the extent of lipid oxidation at initial stages of oxidation [47]. The results of this research with respect to the evolution of this parameter showed a similar behavior to CD formation, evidencing the effect antioxidant of chia flour during the 30 days of frozen storage. It should be noted further that, the peroxide value of optimal burgers remained below 2 milliequivalents of peroxides/kg fat during all 90 days test.

TBARS analysis measures the formation of secondary products of lipid oxidation, mainly malondialdehyde, which contribute to off-flavour of oxidized fat. TBARS values of optimized burger was considerably lower ( $\mathrm{p}$ 0.05) than the control for each sampling during storage, indicating high protection of whole chia flour against lipid oxidation in cooked fish burger.

This antioxidant effect of whole chia flour on the formation of DC, VP and TBARS can be due to the presence of polyphenolic compounds with antiradical activity and reducing power before determined.

\section{Conclusions}

The addition of whole chia flour and water significantly increased the yield, water and fat retention in freshwater fish burgers.

Small amounts of whole chia flour (5.92 g/100g of product) added to the formulation of freshwater fish burgers increased the content of n-3 fatty acids significantly, so that the intake of a burger (100 g approximately) would be enough to cover the daily intake recommendations of international health organizations.

Furthermore, that addition increased significantly the level of polyunsaturated fatty acids and the P/S ratio,

Table 3. Evaluation of lipid oxidation in control formulation (without adding chia flour) and the optimal formulation (added with the whole chia flour), cocked and stored at $-18^{\circ} \mathrm{C}$ for 90 days.

\begin{tabular}{|c|c|c|}
\hline & Control formulation & Optimal formulation \\
\hline Time (days) & \multicolumn{2}{|c|}{ CD (CLA equivalent/g of fat) } \\
\hline 0 & $5.45 \pm 0.06^{\mathrm{b}}$ & $4.70 \pm 0.02^{\mathrm{a}}$ \\
\hline 30 & $5.34 \pm 0.01^{\mathrm{b}}$ & $4.79 \pm 0.10^{\mathrm{a}}$ \\
\hline 60 & $4.85 \pm 0.12^{\mathrm{a}}$ & $4.87 \pm 0.08^{\mathrm{a}}$ \\
\hline \multirow[t]{2}{*}{90} & $5.52 \pm 0.07^{\mathrm{b}}$ & $4.76 \pm 0.12^{\mathrm{a}}$ \\
\hline & \multicolumn{2}{|c|}{ PV (milliequivalent of peroxides/kg fat) } \\
\hline 0 & $2.78 \pm 0.12^{\mathrm{b}}$ & $1.68 \pm 0.10^{\mathrm{a}}$ \\
\hline 30 & $5.09 \pm 0.38^{\mathrm{b}}$ & $1.64 \pm 0.06^{\mathrm{a}}$ \\
\hline 60 & $1.12 \pm 0.05^{\mathrm{a}}$ & $1.57 \pm 0.08^{\mathrm{b}}$ \\
\hline \multirow[t]{2}{*}{90} & $1.69 \pm 0.11^{\mathrm{b}}$ & $1.12 \pm 0.08^{\mathrm{a}}$ \\
\hline & \multicolumn{2}{|c|}{ TBARS (mg MAD/kg fat) } \\
\hline 0 & $9.86 \pm 0.69^{\mathrm{a}}$ & $10.24 \pm 0.72^{\mathrm{a}}$ \\
\hline 30 & $8.68 \pm 0.22^{\mathrm{b}}$ & $4.39 \pm 0.28^{\mathrm{a}}$ \\
\hline 60 & $4.05 \pm 0.22^{\mathrm{a}}$ & $4.48 \pm 0.19^{b}$ \\
\hline 90 & $6.46 \pm 0.32^{\mathrm{b}}$ & $4.39 \pm 0.35^{\mathrm{a}}$ \\
\hline
\end{tabular}

${ }^{*}$ Means \pm standard error. Different letters in the same file indicate significant differences $(\mathrm{p}<0.05)$. CD: Conjugated dienes. PV: peroxide value. TBARS: thiobarbituric acid reactive substances. CLA: conjugated linoleic acid MDA: malondialdehyde. 
and decreased the $n-6 / n-3$ ratio in values less than 1 ; also reduced the IA and the IT indexes and increased the HH index, which represents a positive effect on human health and indicates a more nutritionally suitable food. Furthermore, the chia flour provided the product whit a high content of dietary fiber that improved its nutritional value and exerted an antioxidant effect on the lipids, evidencing oxidative stability on the formation of $\mathrm{CD}, \mathrm{PV}$ and TBARS during 30 days of frozen storage.

This is important because river fish meat with the addition of chia flour can be used as a new product fortified with n-3 fatty acids in regions far from the marina zone. This information will enable the future development of other meat products (chicken, beef, etc.) healthier and with better benefits on human health.

\section{Acknowledgements}

Thanks to UNCAUS (Universidad Nacional del Chaco Austral) and CONICET (Consejo Nacional de Investigaciones Científicas y Técnicas) for supported and financial assistance in this research.

\section{References}

[1] Williams, D., Verghese, M., Walker, L.T., Boateng, J., Shackelford, L. and Chawan, C.B. (2007) Flax Seed Oil and Flax Seed Meal Reduce the Formation of Aberrant Crypt Foci (ACF) in Azoxymethane-Induced Colon Cancer in Fisher 344 Male Rats. Food and Chemical Toxicology, 45, 153-159. http://dx.doi.org/10.1016/j.fct.2006.08.014

[2] Pelser, W.M., Linssen, J.P., Legger, A. and Houben, J.H. (2007) Lipid Oxidation in n-3 Fatty Acid Enriched Dutch style Fermented Sausages. Meat Science, 75, 1-11.

[3] Choi, Y.-S., Park, K.-S., Kim, H.-W., Hwang, K.-E., Song, D.-H., Choi, M.-S., Lee, S.-Y., Paik, H.-D. and Kim, C.-J. (2013) Quality Characteristics of Reduced-Fat Frankfurters with Pork Fat Replaced by Sunflower Seed Oils and Dietary Fiber Extracted from Makgeolli Lees. Meat Science, 93, 652-658. http://dx.doi.org/10.1016/j.meatsci.2012.11.025

[4] Severini, C., De Pilli, T. and Baiano, A. (2003) Partial Substitution of Pork Backfat with Extra-Virgin Olive Oil in "Salami” Products: Effects on Chemical, Physical and Sensorial Quality. Meat Science, 64, 323-331.

[5] Marchetti, L., Andrés, S.C. and Califano, A.N. (2013) Textural and Thermal Properties of Low-Lipid Meat Emulsions Formulated with Fish Oil and Different Binders. LWT_Food Science and Technology, 51, 514-523.

[6] Rahman, A.S., The, S.H., Osman, H. and Daud, N.M. (1995) Fatty Acid Composition of Some Malaysian Freshwater Fish. Food Chemistry, 54, 45-49. http://dx.doi.org/10.1016/0308-8146(95)92660-C

[7] Riernersman, C., Romero, A., Doval, M. and Judis, M.A. (2008) Surubi (Pseudoplatystoma corruscans) de la región NEA como fuente de ácidos grasos omega. XXVII Congreso Argentino de Química "Dr. Pedro José Aymonino", Tucumán.

[8] Filgueras, R.S., Gatellier, P., Ferreira, C., Zambiazi, R.C. and Santé-Lhoutellier, V. (2011) Nutritional Value and Digestion Rate of Rhea Meat Proteins in Association with Storage and Cooking Processes. Meat Science, 89, 6-12. http://dx.doi.org/10.1016/j.meatsci.2011.02.028

[9] Alfaia, C.M.M., Alves, S.P., Lopes, A.F., Fernandes, M.J.E., Costa, A.S.H., Fontes, C.M.G.A., Castro, M.L.F., Bessa Rui, J.B. and Prates, J.A.M. (2010) Effect of Cooking Methods on Fatty Acids, Conjugated Isomers of Linoleic Acid and Nutritional Quality of Beef Intramuscular Fat. Meat Science, 84, 769-777. http://dx.doi.org/10.1016/j.meatsci.2009.11.014

[10] Bilek Elif, A. and Turhan, S. (2009) Enhancement of the Nutritional Status of Beef Patties by Adding Flaxseed Flour. Meat Science, 82, 472-477. http://dx.doi.org/10.1016/j.meatsci.2009.03.002

[11] Velioğlu, H.M., Velioglu, S.D., Boyaci, I.H., Yilmaz, I. and Kurultay, S. (2010) Investigating the Effects of Ingredient Levels on Physical Quality Properties of Cooked Hamburger Patties Using Response Surface Methodology and Image Processing Technology. Meat Science, 84, 477-483. http://dx.doi.org/10.1016/j.meatsci.2009.10.001

[12] Marchetti, L., Andrés, S.C. and Califano, A.N. (2014) Low-Fat Meat Sausages with fish Oil: Optimization of Milk Proteins and Carrageenan Contents Using Response Surface Methodology. Meat Science, 96, 1297-1303. http://dx.doi.org/10.1016/j.meatsci.2013.11.004

[13] Ayerza, R.(h) and Coates, W. (2011) Protein Content, Oil Content and Fatty Acid Profiles as Potential Criteria to Determine the Origin of Commercially Grown Chia (Salvia hispanica L.). Industrial Crops and Products, 34, 1366-1371. http://dx.doi.org/10.1016/j.indcrop.2010.12.007

[14] Elleuch, M., Bedigian, D., Roiseux, O., Besbes, S., Blecker, C. and Attia, H. (2011) Dietary Fibre and Fibre-Rich By-Products of Food Processing: Characterisation, Technological Functionality and Commercial Applications: A Review. Food Chemistry, 124, 411-421. http://dx.doi.org/10.1016/j.foodchem.2010.06.077

[15] Vázquez-Ovando, A., Rosado-Rubio, G., Chel-Guerrero, L. and Betancur-Ancona, D. (2009) Physicochemical Proper- 
ties of a Fibrous Fraction from Chia (Salvia hispanica L.). LWT_Food Science and Technology, 42, 168-173.

[16] Marineli, R.S., Moraes, E.A., Lenquiste, S.A., Godoy, A.T., Eberlin, M.N. and Maróstica Jr., M.R. (2014) Chemical Characterization and Antioxidant Potential of Chilean Chia Seeds and Oil (Salvia hispanica L.) LWT-Food Science and Technology, 59, 1304-1310. http://dx.doi.org/10.1016/j.lwt.2014.04.014

[17] Reyes-Caudillo, E., Tecante, A. and Valvidia-López, M.A. (2008) Dietary Fibre Content and Antioxidant of Phenolic Compounds Present in Mexican Chía (Salvia hispánica L.) Seeds. Food Chemistry, 107, 656-663. http://dx.doi.org/10.1016/j.foodchem.2007.08.062

[18] Myers, R.H. and Montgomery, D.C. (2002) Response Surface Methodology: Process and Product Optimization Using Designed Experiments. Chapter 3, 2nd Edition, Wiley, New York.

[19] Horwitz, W. (Ed.) (2000) Official Methods of Analysis of the Association of Official Analytical Chemists. 17th Edition, AOAC International. AOAC, Maryland, USA.

[20] Bligh, E.G. and Dyer, W.J. (1959) A Rapid Method of Total Lipid Extraction and Purification. Canadian Journal of Biochemistry and Physiology, 37, 911-917. http://dx.doi.org/10.1139/059-099

[21] Ulbricht, T. and Southgate, D. (1991) Coronary Heartdisease: Seven Dietary Factors. Lancet, 338, 985-992. http://dx.doi.org/10.1016/0140-6736(91)91846-M

[22] Santos-Silva, J., Bessa, R.J.B. and Santos-Silva, F. (2002) Effect of Genotype, Feeding System and Slaughter Weight on the Quality of Light Lambs: II. Fatty Acid Composition of Meat. Livestock Production Science, 77, 187-194. http://dx.doi.org/10.1016/S0301-6226(02)00059-3

[23] Singleton, V. and Rossi, J. (1965) Colorimetry of Total Phenolics with Phosphomolybdic-Phosphotungstic Acid Reagents. American Journal of Enology and Viticulture, 16, 144-158.

[24] Kalogeropoulos, N., Yannakopoulou, K., Gioxari, A., Chiou, A. and Makris, D. (2010) Polyphenol Characterization and Encapsulation in $\beta$-Cyclodextrin of Flavonoid-Rich Hypericumperforatum (St John's Wort) Extract. Food Science and Technology, 43, 882-889.

[25] Siddhuraju, P., Mohan, P. and Becker, K. (2002) Studies on the Antioxidant Activity of Indian Laburnum (Cassia fistula L.): A Preliminary Assesment of Crude Extracts from Stem Bark, Leaves, Flowers and Fruit Pulp. Food Chemistry, 79, 61-67. http://dx.doi.org/10.1016/S0308-8146(02)00179-6

[26] Oyaizu, M. (1986) Studies on Products of Browning Reaction-Antioxidative Activities of Products of Browning Reaction. Prepared from Glucosamine, Japanese Journal of Nutrition, 44, 307-315. http://dx.doi.org/10.5264/eiyogakuzashi.44.307

[27] Ponginebbi, L., Nawar, W.W. and Chinachoti, P. (1999) Oxidation of Linoleic Acid in Emulsions: Effect of Substrate, Emulsifier, and Sugar Concentration. Journal of the American Oil Chemists' Society, 76, 131-138. http://dx.doi.org/10.1007/s11746-999-0059-6

[28] International Dairy Federation (1991) FIL-IDF 74A Method: Anhydrous Milkfat, Determination of Peroxide Value.

[29] Romero, A., Doval, M., Sturla, M. and Judis, M.A. (2005) Antioxidant Behaviour of Products Resulting from Beef Sarcoplasmic Proteins-Malondialdehyde Reaction. European Journal of Lipid Science and Technology, 107, 903-911. http://dx.doi.org/10.1002/ejlt.200501196

[30] Valenzuela Melendres, M., Camou, J.P., Torrentera Olivera, N.G., Alvarez Almora, E., Gonzales Mendoza, D., Avendaño Reyes, L. and Gongalez Ríos, H. (2014) Response Surface Methodology for Predicting Quality Characteristics of Beef Patties Added with Flaxseed and Tomato Paste. Meat Science, 97, 54-61. http://dx.doi.org/10.1016/j.meatsci.2014.01.007

[31] Anderson, E.T. and Berry, B.W. (2001) Effects of Inner Pea Fiber on Fat Retention and Cooking Yield in High Fat Ground Beef. Food Research International, 34, 689-694. http://dx.doi.org/10.1016/S0963-9969(01)00089-8

[32] Gök, V., Akkaya, L., Obuz, E. and Bulut, S. (2011) Effect of Ground Poppy Seed as Fat Replacer on Meat Burgers. Meat Science, 89, 400-404. http://dx.doi.org/10.1016/j.meatsci.2011.04.032

[33] Delgado-Pando, G., Cofrades, S., Ruiz-Capillas, C., Solas, M.T. and Jimenez-Colmenero, F. (2010) Healthier Lipid Combination Oil-in-Water Emulsions Prepared with Various Protein Systems: An Approach for Development of Functional Meat Products. European Journal of Lipid Science and Technology, 112, 791-801. http://dx.doi.org/10.1002/ejlt.200900234

[34] Wood, J.D., Richardson, R.I., Nute, G.R., Fisher, A.V., Campo, M.M. and Kasapidou, E. (2003) Effects of Fatty Acids on Meat Quality: A Review. Meat Science, 66, 21-32. http://dx.doi.org/10.1016/S0309-1740(03)00022-6

[35] Simopoulos, A.P. (2013) Omega-3 Polyunsaturated Fatty Acids: Nutrigenetic and Nutrigenomic Aspects in the Determination of Dietary Requirements, Development, and Chronic Diseases. In: Caballero, B., Ed. (In-Chief), Encyclopedia of Human Nutrition, 3rd Edition, Academic Press, Cambridge, 405-412.

http://dx.doi.org/10.1016/b978-0-12-375083-9.00099-4 
[36] WHO (2003) Diet, Nutrition and the Prevention of Chronic Diseases. WHO Technical Report Series 916. Switzerland, Geneva. http://www.fao.org/docrep/005/AC911E/AC911E00.HTM

[37] Tonial, I.B., Bravo, C.E.C., Souza, N.E., Matsushita, M., Furuya, W.M. and Visentainer, J.V. (2011) Qualidade nutricional dos lipídios de tilápias (Oreochromisniloticus) alimentadas comração suplementada com óleo de soja. Alimentos e Nutrição, 22, 103-112.

[38] Salcedo-Sandoval, L., Cofrades, S., Ruiz-Capillas Pérez, C., Solas, M.T. and Jiménez-Colmenero, F. (2013) Healthier Oils Stabilized in Konjac Matrix as Fat Replacers in n-3 PUFA Enriched Frankfurters. Meat Science, 93, 757-766. http://dx.doi.org/10.1016/j.meatsci.2012.11.038

[39] Fuchs, R.H.B., Ribeiro, R.P., Matsushita, M., Tanamati, A.A.C., Bona, E. and Pereira de Souza, A.H. (2013) Enhancement of the Nutritional Status of Nile tilapia (Oreochro misniloticus) Croquettes by Adding Flaxseed Flour. LWT_Food Science and Technology, 54, 440-446. http://dx.doi.org/10.1016/j.lwt.2013.07.004

[40] Mohdaly, A., Smetanska, I., Ramadan, M.F., Sarhan, M.A. and Mahmoud, A. (2011) Antioxidant Potential of Sesame (Sesamum indicum) Cake Extract in Stabilization of Sunflower and Soybean Oils. Industrial Crops and Products, 34, 952-959. http://dx.doi.org/10.1016/j.indcrop.2011.02.018

[41] Alimpic, A., Pljevljakusi, D., Savikin, K., Knezevi, A., Cur, M., Velickovi, D., Stevic, T., Petrovic, G., Matevskif, V., Vukojevic, J., Markovic, S., Marina, P.D. and Duletic-Lausevi, S. (2015) Composition and Biological Effects of Salvia ringens (Lamiaceae) Essential Oil and Extracts. Industrial Crops and Products, 76, 702-709. http://dx.doi.org/10.1016/j.indcrop.2015.07.053

[42] Chaalal, M., Louaileche, H., Touati, N. and BachirBey, M. (2013) Phytochemicals, in Vitro Antioxidant Capacity and Antiradical Potential of Whole and Ground Seeds of Three Prickly Pear Varieties: A Comparative Study. Industrial Crops and Products, 49, 386-391. http://dx.doi.org/10.1016/j.indcrop.2013.05.010

[43] Amarowicz, R., Naczk, M. and Shahidi, F. (2000) Antioxidant Activity of Crude Tannins of Canola and Rapeseed Hulls. Journal of the American Oil Chemists' Society, 77, 957-961. http://dx.doi.org/10.1007/s11746-000-0151-0

[44] Duh, P.-D. and Yen, G.-C. (1997) Antioxidant Activity of Three Herbal Water Extracts. Food Chemistry, 60, 639-645. http://dx.doi.org/10.1016/S0308-8146(97)00049-6

[45] Manian, R., Anusuya, N., Siddhuraju, P. and Manian, S. (2008) The Antioxidant Activity and Free Radical Scavenging Potential of Two Different Solvent Extracts of Camellia sinensis (L.) O. Kuntz, Ficus bengalensis L. and Ficus racemosa L. Food Chemistry, 107, 1000-1007. http://dx.doi.org/10.1016/j.foodchem.2007.09.008

[46] Rumbaoa, R., Cornago, D. and Geronimo, I. (2009) Phenolic Content and Antioxidant Capacity of Philippine Sweet Potato (Ipomoea batatas) Varieties. Food Chemistry, 113, 1133-1138. http://dx.doi.org/10.1016/j.foodchem.2008.08.088

[47] Teets, A.S. and Were, L.M. (2008) Inhibition of Lipid Oxidation in Refrigerated and Frozen Salted Raw Minced Chicken Breasts with Electron Beam Irradiated Almond Skin Powder. Meat Science, 80, 1326-1332. http://dx.doi.org/10.1016/j.meatsci.2008.06.010

\section{Submit or recommend next manuscript to SCIRP and we will provide best service for you:}

Accepting pre-submission inquiries through Email, Facebook, LinkedIn, Twitter, etc.

A wide selection of journals (inclusive of 9 subjects, more than 200 journals)

Providing 24-hour high-quality service

User-friendly online submission system

Fair and swift peer-review system

Efficient typesetting and proofreading procedure

Display of the result of downloads and visits, as well as the number of cited articles

Maximum dissemination of your research work

Submit your manuscript at: http://papersubmission.scirp.org/ 